\title{
Article/Artigo
}

\section{Dynamics of Capillaria-hepatica-induced hepatic septal fibrosis in rats}

\author{
Dinâmica da fibrose septal hepática induzida por Capillaria hepatica em ratos
}

\author{
Lidiane Gaban", Cleber Douglas Lucinio Ramos², Aryon Almeida Barbosa Júnior ${ }^{1}$, Márcia Maria de Souza ${ }^{1,3}$ \\ and Zilton de Araújo Andrade ${ }^{1}$
}

\begin{abstract}
Introduction: The pathogenesis of septal hepatic fibrosis, induced in rats by Capillaria hepatica infection, was studied with the aid of a large collection of stored paraffin blocks, representative of the different evolutive phases of fibrosis which appeared in 100\% of infected rats. Methods: Studies were conducted involving histology, immunohistochemistry, immunofluorescence and morphometric methods, in order to observe the dynamic behavior of the cellular and matrix components of fibrosis, over a one year period of evolution. Results: Observation verified that septal fibrosis originates from several portal spaces simultaneously. Its origin and progression involve blood vessel proliferation (angiogenesis), multiplication of actinpositive cells (pericytes and myofibroblasts) and progressive collagen deposition. By the end of 4-5 months, a progressive decrease in all these components was observed, when signs of regression of septal fibrosis became more evident over time. Conclusions: Besides indicating the fundamental role played by angiogenesis in the pathogenesis of fibrosis, these morphological data concerning the dynamics of this $C$. hepatica experimental model proved to be adequate for future investigations regarding the functional aspects of fibrosis induction, progression and regression.
\end{abstract}

Key-words: Angiogenesis. Septal fibrosis. Capillaria hepatica.

\section{RESUMO}

Introdução: Um extenso material de patologia experimental arquivado em blocos de parafina, ilustrativo das diferentes fases da fibrose hepática septal, que 100\% dos ratos desenvolvem em seguida uma infecção com o nematódeo Capillaria hepatica. Métodos: O material foi sistematicamente estudado com métodos morfológicos e morfométricos, no sentido de se verificar o comportamento dos elementos celulares e matriciais durante a evolução da fibrose hepática septal ao longo de um período de um ano. Resultados: Foi constatado que a fibrose septal se origina de vários espaços porta ao mesmo tempo, com proliferação vascular (angiogênese), multiplicação de células actino-positivas (pericitos, miofibroblastas) e progressivo depósito de colágeno. Ao fim dos 4-5 meses há uma involução regressiva de todos estes indícios morfológicos, mas com alguns septos persistindo bem evidentes até o fim de um ano. Conclusões: Além de ilustrar o papel fundamental desempenhado pela angiogênese, o modelo se mostrou adequado para futuros estudos funcionais relacionados com a indução, progressão e regressão da fibrose hepática.

Palavras-chaves: Angiogênese. Fibrose septal. Capillaria hepatica.

\footnotetext{
1. Laboratory of Experimental Pathology, Gonçalo Moniz Research Center, Oswaldo Cruz Foundation, Salvador, BA, Brazil. 2. Biomedicine Departament, Goiás Federal University, Jataí, GO, Brazil. 3. Biology Departament, Histology Laboratory, Feira de Santana State University, Feira de Santana, BA, Brazil. Address to: Dr. Zilton de Araújo Andrade. LAPEX/CPqGM/FIOCRUZ. Rua Valdemar Falcão 121, Brotas, 40295-001 Salvador, BA, Brazil.

Phone: 5571 3176-2206

e-mail: zilton@bahia.fiocruz.br

Received in 01/06/2010

Accepted in 27/07/2010
}

\section{INTRODUCTION}

Hepatic fibrosis is a common complication for many types of hepatic diseases, especially those that are inflammatory, but its pathogenesis still presents complex features that keep stimulating research ${ }^{1,2}$. Recently, the concept that any fibrosis, irrespective of the involved organ, represents a classical process of repair, where angiogenesis (granulation tissue) plays a fundamental role, has become increasingly recognized ${ }^{3-6}$.

Furthermore, recent data from our laboratory have indicated a dual and paradoxical role for angiogenesis, since it is ostensibly present not only during fibrosis formation ${ }^{7}$, but also during fibrosis regression ${ }^{8}$. These dynamic aspects of fibrogenesis appeared suitable for investigation with the aid of a peculiar experimental model of hepatic fibrosis, one which appears in $100 \%$ of rats infected with nematode worm Capillaria hepatica.

Rats infected with the nematode $C$. hepatica invariably develop a peculiar process of diffuse septal fibrosis of the liver that starts within 14-18 days following infection, becomes progressively intensified during the following 2-3 months and then gradually decreases thereafter, remaining as a few, scattered, thin vascular fibrous septa, from six months up to at least a year. The reasons for this peculiar course of $C$. hepatica-induced liver fibrosis are certainly related to host-parasite interactions, but the precise factors and mechanisms involved are not yet fully understood. However, the peculiarities of this experimental model of liver fibrosis may be explored for the study of several features of hepatic fibrosis biology, especially those related to dynamic changes in the cellular and matrix that occur at fibrosis initiation, progression, and regression.

The present paper is concerned with the participation of angiogenesis, particularly of its cellular components, pericytes and endothelium, as well as the associated matrix morphological changes that occur during several representative periods of time over the course of a year, in rats experimentally infected with C. hepatica. Particular attention was paid to the behavior of these elements during the periods of induction, progression and regression of septal fibrosis of the liver. 


\section{METHODS}

\section{Material}

Formalin-fixed paraffin-embedded blocks of the livers of adult Wistar rats, which had been infected with $C$. hepatica, were selected from the files of our laboratory. The rats, males and females, weighing 200-300g, had been infected with approximately 500 embryonated C. hepatica eggs, administered by gavage (see details in Souza et $\mathrm{al}^{9}$ ). Selection of the blocks was made in order to represent different periods of the time of infection. Such periods ranged from 10, 14, 20 and 50 days up to 4, 6 and 12 months. At least 5 paraffin blocks were selected for each time period.

\section{Techniques}

Histopathology

The blocks were routinely cut into $5 \mu \mathrm{m}$-thick sections that were submitted to staining with either hematoxilin-eosin or sirius-red for collagen.

\section{Immunofluorescence}

The indirect immunofluorescence technique was used to demonstrate either $C$. hepatica antigens or laminin. Antigen retrieval was achieved through microwave treatment in citrate buffer at $\mathrm{pH}$ 6.0. The sections were then treated with anti-laminin serum (Institute Pasteur, France) and submitted to serum from C. hepatica-infected mice used at variable dilutions, followed by fluoresceinated anti-mouse IgG, commercially obtained from Sigma (Mo USA).

\section{Immunohistochemistry}

Paraffin sections were placed on slides previously treated with 10\% Poly-L-Lisin, fixed in dehydrated acetone and treated with PBS. For blockade of nonspecific ligations, the sections were treated with $10 \%$ skimmed milk in PBS for $20 \mathrm{~min}$ at room temperature. Antigen retrieval was achieved through microwave treatment in citrate buffer at $\mathrm{pH}$ 6.0. The sections were incubated with the primary antibody overnight at $4^{\circ} \mathrm{C}$ in a humidified chamber. Primary antibody was diluted in 2\% BSA in PBS ( $\mathrm{pH}$ 7.4). After washing in PBS, the sections were incubated with the secondary antibody: a sheep-anti-Rat IgG conjugated to Peroxidase (Dako envision system - labeled polymer, Dakopatts, Denmark) at a dilution of $1: 1,000$ for $30 \mathrm{~min}$ at $37^{\circ} \mathrm{C}$ in a humidified chamber. Blockage of the endogenous peroxidase was performed with $0.3 \% \mathrm{H}_{2} \mathrm{O}_{2}$ for $30 \mathrm{~min}$ at room temperature. The color was developed with $0.06 \% 3,3$ '-diaminobenzidine tetrahydrochloride (DAB) and $0.06 \% \mathrm{H}_{2} \mathrm{O}_{2}$ plus $1 \%$ dimethylsulphoxide. The sections were counterstained with hematoxilin for $2 \mathrm{~min}$, dehydrated and mounted with Canadian balsam. Control sections in which primary antibody was either omitted or replaced by normal rat serum, were used. To demonstrate SM- $\alpha$ actin (mouse anti-SM- $\alpha$ actin, clone 1A4, DAKO), paraffin sections of formalin-fixed tissue were used.

\section{Morphometry}

Quantitative estimation of the number of actin-positive cells and the amount of fibrous tissue within the septa was performed on liver histological sections using the Leica QWIN 3.1, Image Processing and Analysis System (Leica Cambridge, Cambridge, UK). For morphometric measurements, a total sectional area of $5.0 \times 10 \mathrm{~mm}^{2}$ per case was evaluated. Automatic morphometric analysis was performed in a similar manner to that previously described ${ }^{10,11}$. Briefly, the actin-positive cells present within the sectional area were all counted.

\section{RESULTS}

Sections of the liver from any period of infection regularly showed parasite-related lesions. They were represented by granulomatous lesions distributed throughout the parenchyma. The center of these lesions contained preserved or decaying worms and eggs and were surrounded by a fibrous capsule. As time passed, more or less resorption of the inflammation and the parasitic elements was observed, but the eggs tended to be preserved and became more concentrated. The earliest portal fibrous septa were detected in material taken after day 14 postinfection. They appeared predominantly cellular, with proliferating mesenchymal cells, blood capillaries and fine collagen fibers in between these elements. The application of special techniques showed that the number of actin-positive cells (Figure 1), mainly pericytes and myofibroblasts (Figure 2), gradually increased with time up to the $4^{\text {th }}$ month following infection, and then gradually decreasing toward the end of one year (Figure 2). The same was true for the presence of collagen within the septa (Figure 3). Numerous actin-positive cells were observed among the cells within the parasitic granulomas and within the fibrous portal septa, while the relative concentration of these elements ran parallel to that of collagen. The presence of proliferating blood vessels was observed by staining their basement membrane with fluorescent anti-laminin antibodies (Figure 4).

From the $6^{\text {th }}$ month of infection onward, progressive thinning of the fibrous septa was observed. In sections representative of late infection (one-year duration), most of the septa appeared as empty clefts, but a few persisted as fine tracts, sometimes with blood vessel connections portal to sinusoids or to other vessels in portal spaces. Encapsulated collections of eggs appeared isolated inside the liver parenchyma during the entire experimental period.

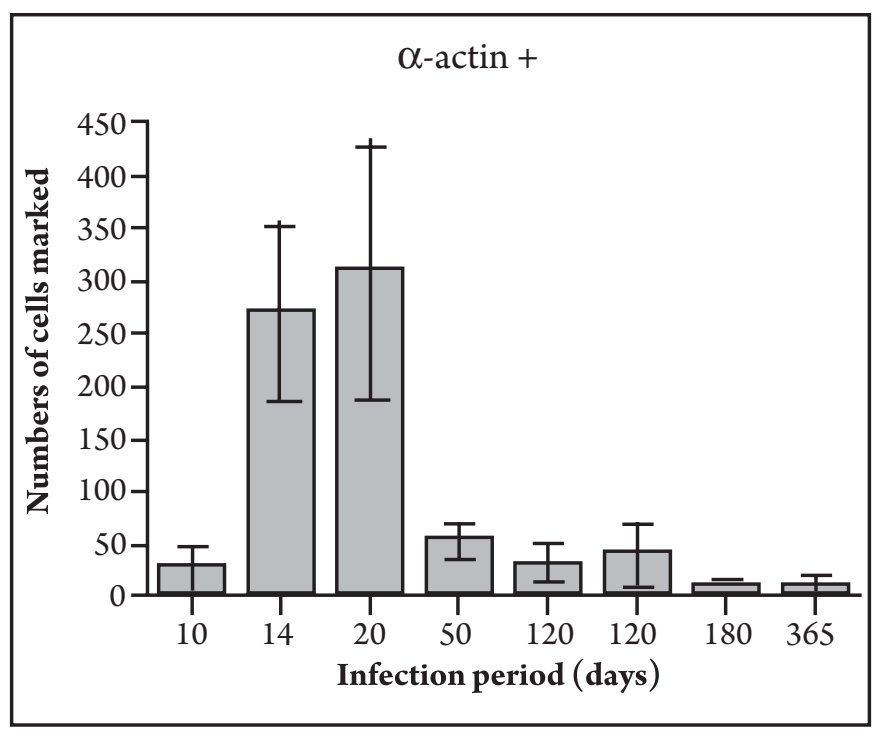

FIGURE 1 - Morphometric evaluation of cells stained with anti-smooth muscle actin- $\alpha$. The bars represent the numbers of cells marked with anti-smooth muscle actin- $\alpha$ at different periods of $C$. hepatica infection in rats, revealing the crucial participation of pericytes and myofibroblast during the periods of fibrosis induction and progression. 


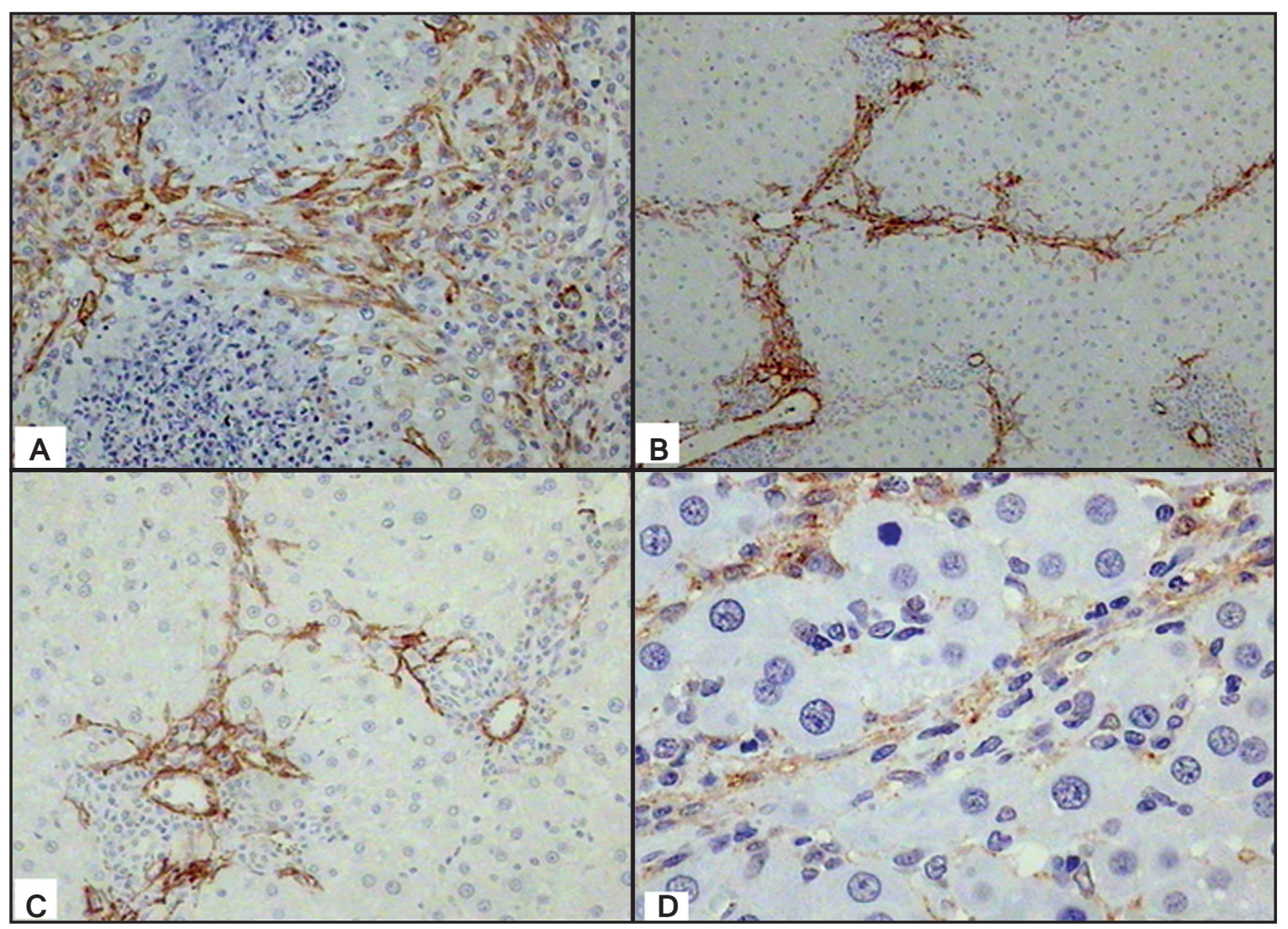

FIGURE 2 - Alpha-actin containing cells in septal fibrosis. A: Alpha-actin positive cells appear in great numbers on the growing septa being formed between two neighboring portal spaces, as seen by day 20 postinfection. 200x. B: Four months postinfection, actin-positive cells appear more concentrated and polarized within the septa. 200X. C: At 6 months following infection, actin staining reveals an image of involution of the septa compared to earlier images. 100X. D: A single thin septum is seen traversing this photo, as detected in a rat with a one year-old infection. Signs of involution are advanced, but actin-positive cells remain. 200X Immunostaining for alpha Smooth Muscle Actin.

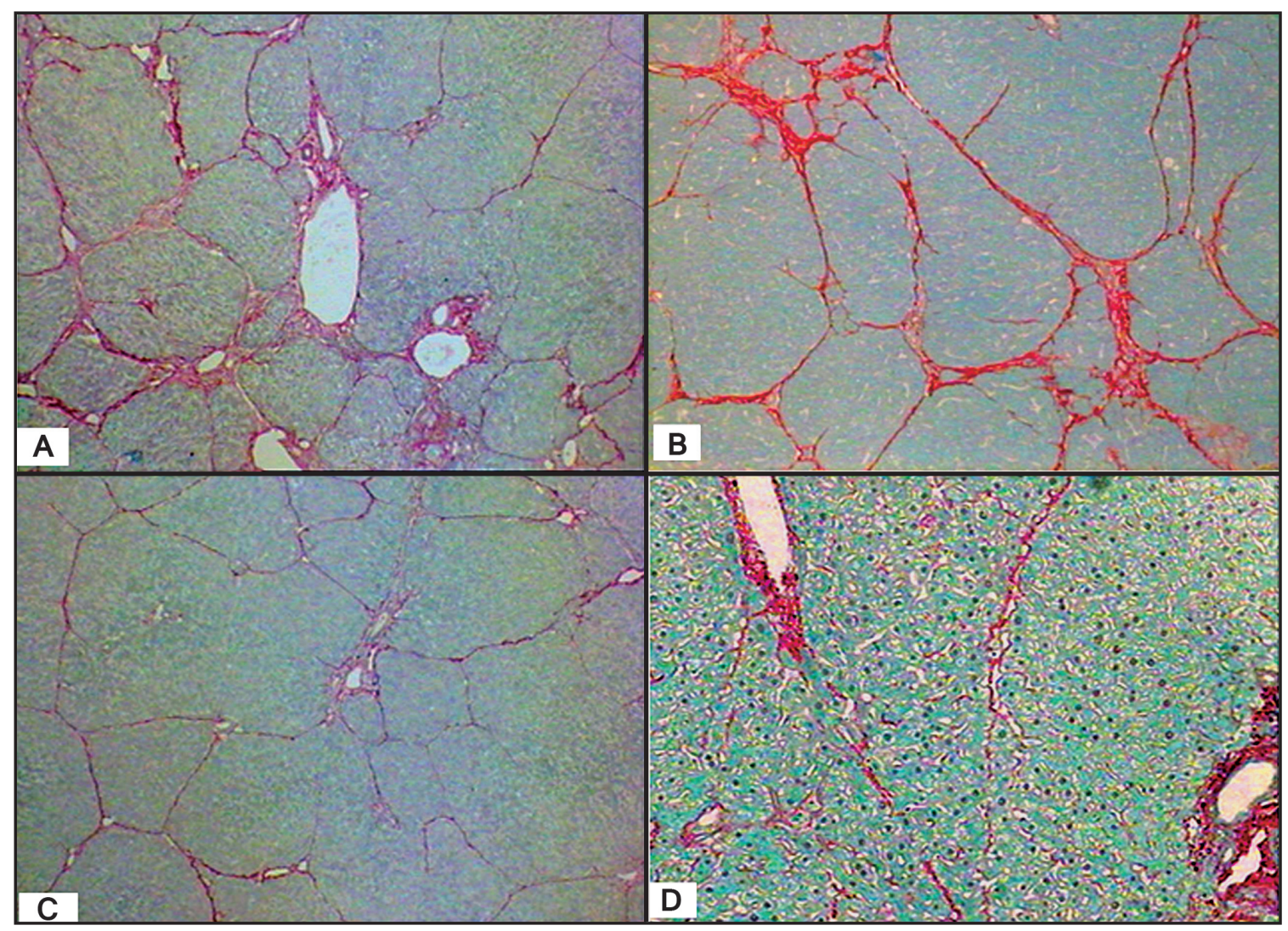

FIGURE 3 - This plate depicts several changing aspects of the distribution of collagen fibers and fibrils along fibrous septa formed at different times of C. hepatica infection in rats. A:100X, 20 days. B: 200X, 50 days. C: 100X, 6 months. D: 100X, One year. Sirius-red staining method. 


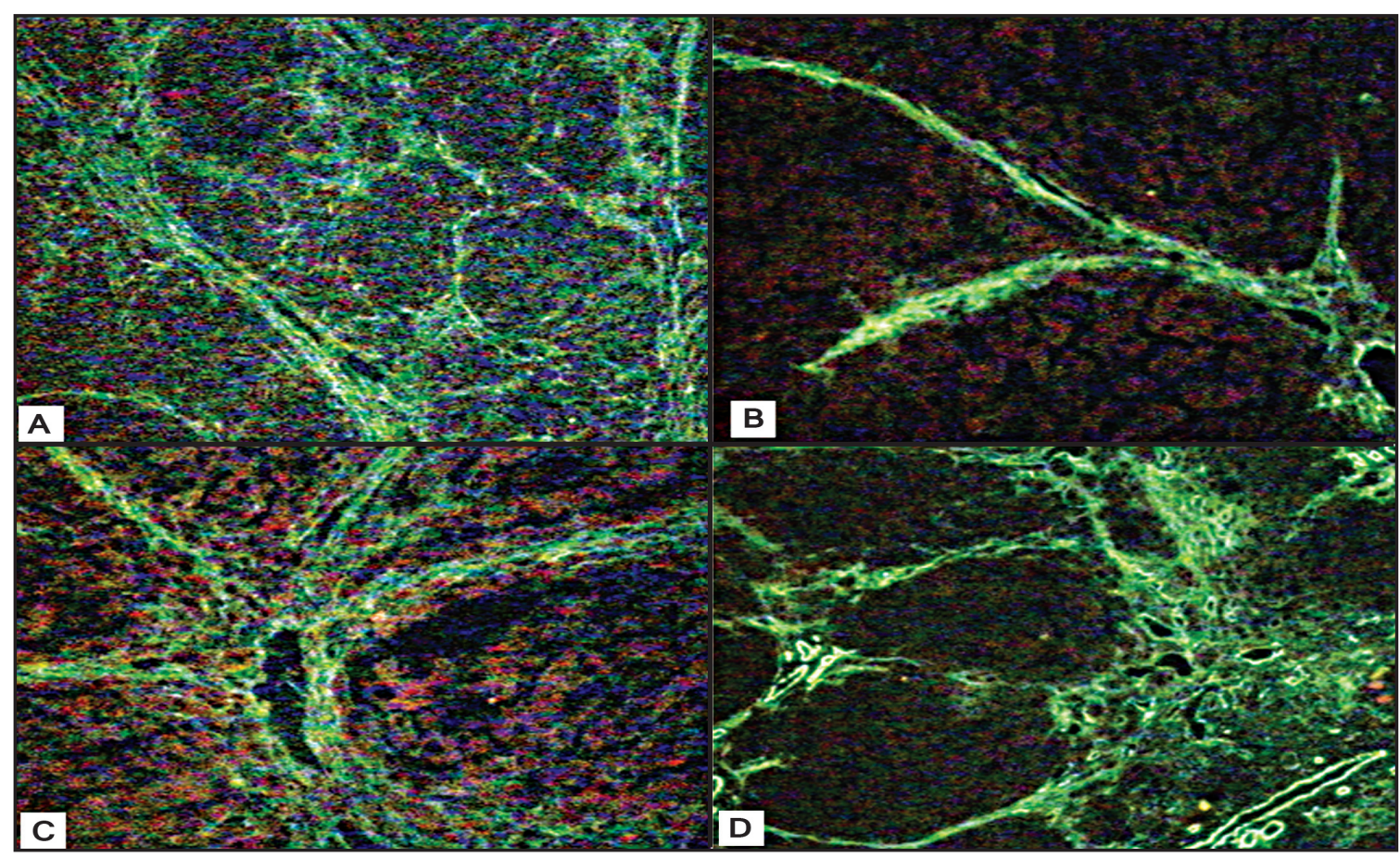

FIGURE 4 - These photos show the presence of laminin, a marker for basement membranes, especially from blood vessels. The rich vascularization of the septa is depicted herein to illustrate the dynamic variation of the process of angiogenesis over time. A: 100X, 20 days. B: 200X, 40 days. C: 200X, 50 days. D: 200X, 4 months. Indirect Immunofluorescence technique.

\section{DISCUSSION}

Previous studies with the rat $C$. hepatica model revealed the important role played by angiogenesis during hepatic septal fibrosis development ${ }^{9}$. Not only was the presence of proliferating blood capillaries prominent within the sprouting of the first septa, but this presence was seen to precede collagen deposition ${ }^{12}$. The principal dynamic stages of septal fibrosis formation, including initiation, progression and regression over the course of one year, were described in a previous study ${ }^{9}$. The present study revealed that, by specifically marking the vascular (actin-positive pericytes) and interstitial elements (collagen and myofibroblasts) in histological sections, it was possible to demonstrate the primary and fundamental participation of angiogenesis in the pathogenesis of septal fibrosis. Alpha-actin staining was fundamental in revealing positive cells that could be easily followed and counted over several time-periods. These positive cells in the septa represented mainly pericytes and myofibroblasts and, occasionally, smooth muscle cells within small veins and arterioles, which were relatively rare in the thin fibrous septa. When considered together with the collagen staining results, the findings once again revealed the close association between vascular proliferation and fibrosis formation and, later on, the inverse relation during fibrosis regression. Thus, the rat $C$. hepatica model proved to be an adequate tool for future studies concerned with the relation between angiogenesis and fibrosis and with morphological and functional aspects related to the different steps involved during induction, progression and regression of hepatic fibrosis.

\section{CONFLICT OF INTEREST}

The authors declare that there is no conflict of interest.

\section{FINANCIAL SUPPORT}

Conselho Nacional de Desenvolvimento Científico e Tecnológico.

\section{REFERENCES}

1. Friedman SL. Liver Fibrosis - From bench to bedside. J Hepatol 2003; 38:38-53.

2. Battaler R, Brenner DA. Liver fibrosis. J Clin Invest 2005; 115: 209-218.

3. Gerhardt H, Betsholtz C. Endothelial-pericyte interactions in angiogenesis. Cell Tissue Res 2003; 314:15-23.

4. Fernandez M, Semela D, Bruiz J, Colle I, Pinzani M, Bosch J. Angiogenesis in liver fibrosis J. Hepatol 2009; 50: 604-620.

5. Guyot C, Lepreux S, Combea C, Doudnikoff E, Bioulac-Sage P, Balabaud C, et al. Hepatic fibrosis and cirrhosis: The (myo)fibroblastic cell subpopulations involved. Inst J Biochem Cell Biol 2006; 38:135-151.

6. Lee JS, Semela D, Iredale J, Shah V. Sinusoidal remodeling and Angiogenesis: A New Funtion for the Liver-Specific Pericyte? 2007; 45: 817-825.

7. Baptista AP, Andrade ZA. Angiogenesis and schistosomal granuloma formation. Mem Inst Oswaldo Cruz 2005; 100:183-185.

8. Andrade ZA, Baptista AP, Santana TS. Remodeling of hepatic vascular changes after specific chemotherapy of schistosomal periportal fibrosis. Mem Inst Oswaldo Cruz 2006; 101:267-272.

9. Souza MM, Junior MT, Assis BCA, Gonzales ACO, Silva TMC, Andrade ZA. Pathogenesis of septal fibrosis of the liver. An experimental study with a new model. Pathol Res Pract 2006; 202:883-889.

10. Barbosa-Jr AA. Morphological computer-assisted quantitiative estimation of stained fibrous tissue in liver sections: applications in diagnosis and experimental research J Bras Patol 2001; 37:197-200.

11. Vieira MG, Oliveira F, Arruda S, Bittencourt AL, Barbosa-Jr AA, Barral-Netto M, et al. B-cell infiltration and frequency of cytokine producing cells differ between localized and disseminated human cutaneous leishmaniases. Mem Inst Oswaldo Cruz 2002; 97: 979-983.

12. Souza MM, Tolentino-Jr M, Assis BC, Gonzalez ACO, Silva TMC, Andrade ZA. Significance and fate of septal fibrosis of the liver. Hepatol Res 2006; 35:31-36. 